\begin{tabular}{|c|c|c|}
\hline EREM 74/2 & \multicolumn{2}{|c|}{$\begin{array}{c}\text { Solid Waste Management in Educational Institutions: } \\
\text { The Case of The University of Jordan }\end{array}$} \\
\hline $\begin{array}{l}\text { Vol. } 74 \text { / No. } 2 \text { / } 2018 \\
\text { pp. 23-33 }\end{array}$ & Received 2018/06 & Accepted after revision 2018/08 \\
\hline (1) Kaunas University of Technology & \multicolumn{2}{|c|}{ crossef http://dx.doi.org/10.5755/j01.erem.74.2.21037 } \\
\hline
\end{tabular}

\title{
Solid Waste Management in Educational Institutions: The Case of The University of Jordan
}

\section{Shadi Moqbel}

Assistant professor, Civil Engineering Department, The University of Jordan. Queen Rania St. Amman 11942, Jordan

Corresponding author: s.moqbel@ju.edu.jo

Shadi Moqbel, Civil Engineering Department, The University of Jordan. Queen Rania St. Amman 11942, Jordan

Tel: 00962-6-5355000 ext 22742

Sustainable development has forced developing countries to have a focused look at their waste management system including educational institutions. In this work, a waste characterization study was conducted at the University of Jordan. A simple method for characterizing solid waste is proposed for high intensity institutions. The study included estimation of waste generation rate, characterization of the solid waste generated on campus and it's variation over four distinct periods during the academic calendar: regular semester, study break, summer semester and the month of Ramadan. Exploring the study results, recycling potential was evaluated. The study revealed that in regular semesters the university campus produces an average of $8113 \mathrm{~kg}$ of waste per day. The results show that at least $87 \%$ of the waste generated on campus may be recycled. To ensure sustainable solid waste management and reliable recycling program, a university run program must be operated.

Keywords: Solid waste, characterization, recycling, educational institution.

\section{Introduction}

Educational institutions such as universities can be considered as small communities that have significant impact on surrounding urban areas (Armijo de Vega et al, 2003; Taghizadeh et al, 2012). Furthermore, solid waste management in educational institutions can informally train students to practice good solid waste management approaches and take this experience back to their homes. Therefore, successful approaches and practices can be easily adopted by surrounding communities (Armijo de Vega et al, 2008). 
Accordingly, solid waste management in educational institutions is gaining more seriousness in detailing and evaluation of resources recovery and recycling possibilities (Smyth et al, 2010). Adopting zero-waste policy among educational institutions have been shown to be achievable but requires full scale cooperation. Mason et al (2003) evaluated the zero-waste program and environmental management structures at Massey University campus, New Zealand. The study showed that linkage between all involved sectors is needed to have a successful program and exhibited the necessity of including a formal waste management system. Armijo de Vega et al (2003) conducted similar work and presented the development of a recycling program at the Autonomous University of Baja California. The study concluded that such programs require the involvement of different parties at the different levels within the University.

Sustainable and integrated solid waste management plan incorporating fully developed recycling programs at institutional level became an obvious need. Generally, educational institutions in developing countries are running their solid waste management programs individually or with huge reliance on their governments. A reference framework for solid waste management in educational institutions is needed (Armijo de Vega et al, 2008). Currently, recycling became one of the profound measures the universities can take to show commitment to environmentally sound practices (Armijo de Vega et al 2008). However, such plan requires comprehensive data on present and anticipated waste generation situation to build knowledge and estimate capacity to develop satisfactory plans and systems (UNEP, 2009). Moreover, composition and characteristics of solid waste are subjected to variation caused by many parameters (Tchobanoglous et al, 1996). Among these parameters are season and culture which cause major differences in characteristics between one location and the other. Full understanding of the solid waste management necessitates good knowledge of the waste generated and the temporal variation (Felder et al, 2001; Taghizadeh et al, 2012; Sebola et al 2014). Review of literature shows that integrated waste management systems developed within universities are evolving to understand current conditions and recycling opportunities in universities. Felder et al (2001) performed a waste audit study to determine the characteristics of solid waste generated on the University of British Columbia, Canada for waste reduction programs. The study reported that average amount of waste produced from the campus for the period (1996-1999) was 2834 tonne /year. The study sampled $1832 \mathrm{~kg}$ of waste, $61 \%$ of this waste was compostable, $19 \%$ recyclable and $20 \%$ residual waste. Mbuligwe (2002) studied the waste characteristics and solid waste management practices in three academic institutions in Tanzania. These reported institutions are considered relatively small institutions. Populations in these institutions were 4732, 610 and 170. The study did not show if it considered the variation in composition with time and major events. Armijo de Vega et al (2008) conducted a characterization study to evaluate the recycling potential at the Autonomous University of Baja California in Mexico. The study estimated waste generated from three types of sources: buildings, gardens and community centre. The study showed that average daily generation of waste from this campus was 1 tonne/day. The researchers sampled a total of $4800 \mathrm{~kg}$ of waste. This waste was divided into $32 \%$ recyclable material, $34 \%$ potentially recyclable material, and $34 \%$ non-recyclable waste. Smyth et al (2010) studied the characteristics of waste generated from key areas at the Prince George campus of the University of Northern British Columbia. The study did not consider all buildings within the university campus. The study estimated an amount of $302 \mathrm{~kg} /$ day of waste generated from the Prince George campus. The researchers sampled $1359 \mathrm{~kg}$ of waste. Their waste composed of $37 \%$ recyclable material, 19\% compostable and 35\% non-recyclable material. Taghizadeh et al (2012) conducted a characterization study for the waste generated from the University of Tabriz, Iran. The study showed that average daily waste generation was about 2.5 tonne/day. Their waste is composed of $45 \%$ compostable material, $37 \%$ recyclable material, $18 \%$ non-recyclable material. Sebola et al (2014) performed a simple characterization and quantification study of the garden waste and general waste over a 
period of five weeks at the University of Johannesburg, South Africa. The University of Johannesburg hosts 8000 students and already have an existing waste management system. The study reported that the university campus generates approximately $310 \mathrm{~kg}$ of waste per day. $65.21 \%$ of this waste is general waste. The study reported that their general waste was composed of $67.36 \%$ food, $11.24 \%$ other biodegradable material, $1.67 \%$ polystyrene, $19.73 \%$ Non-categorized. Their garden waste is composed of 93\% compostable material and 7\% non-compostable material. Following the results of these studies, it can be concluded that each educational institution is a special case of study. Furthermore, a common notice on these studies, they did not show that they considered variation in solid waste composition with time. Moreover, no data have been found in literature on solid waste generation and waste characteristics for large size campuses (e.g. over 40,000 students).

The University of Jordan is the largest governmental educational institution in Jordan. Currently, it hosts 24 schools, over 41,000 students, 1543 faculty members and 2950 administrative staff. In response to the national sustainability plan of action, the university announced it's strategic sustainability goals: Funding and investment, Safe environment, Smart University, Best management and governance, and High quality.

In applying the safe environment, the university administration moved from traditional paper documents to electronic documents. Also, the university sought recycling contractors to recycle excess paper produced from it's print office. Over the history of the university, many recycling initiatives and campus greening calls were raised. The consecutive administrations of the university supported several of these solid waste recycling initiatives. These initiatives were usually empowered by care and enthusiasm for the environment by groups of students and faculty members. However, these initiatives lacked sustainable management, awareness, and full involvement of the administration. Therefore, these initiatives faded with time. Until the time of production of this work, neither the university of Jordan nor any other educational institution in Jordan have a full-scale and comprehensive recycling program covering the entire campus.
This project has been conducted to obtain reliable information on the current waste generation status and explore potential recycling opportunities. The study investigated the generation rate of solid waste and characteristics of the entire stream of solid waste in the main campus of the University of Jordan and the variation in waste composition over the school academic calendar and main events. Four periods have been identified to investigate the variation: Regular semester, study break between semesters, summer semesters and the month of Ramadan, a month during which Muslims fast from sunrise to sunset. Following the characterization study, the potential of recycling solid waste on the main campus has been explored and recommendations have been put for the university administration to achieve waste reduction.

\section{Case description}

The University of Jordan main campus is located in Amman and it is surrounded by wire fence with gates designated for students, faculty members, administrative staff, on-campus community centres personal and academic visitors access. The campus includes over 60 buildings for the various uses. These buildings include academic, administrative, gardening, community centre, main restaurant, engineering workshops, dormitories and a hospital. During the academic year 2016/2017 the university administration decided to experiment having two condensed summer semesters covering in total 70 days. This study took place over the academic semesters and breaks of the year 2017; Spring semester, first summer semester, second summer semester, fall semester. Students enrolment during these periods are listed as table 1. A total of 67 solid waste containers, size of $1100 \mathrm{~L}$, were serving the various buildings inside the campus area. Locations of containers serving faculties and administrative buildings are illustrated in Fig. 1.

Dormitories and the hospital wastes were not included since their waste bins were located outside the fenced area. Hazardous waste from health schools and scientific schools is handled separately according to an agreement the university administration had made with the ministry of environment to have 
a separated collection method, therefore, hazardous waste was not considered in this study.

Waste containers sometimes serve buildings of different activities. Some containers serve gardening services, administration and academic building at the same time. Some schools are close to small shops and commercial services areas. Also, some school buildings host small cafeteria inside it. As a result, separating waste according to source could not be achieved. Therefore, characterization was conducted to the containers content regardless of the contributor.

\section{Table 1}

Number of active students on campus during academic semesters of the year 2017

\begin{tabular}{l|c}
\hline \multicolumn{1}{c|}{ Semester } & Active students on campus \\
\hline 1 & 2 \\
\hline Spring semester & 41513 \\
\hline $1^{\text {st }}$ Summer semester & 23845 \\
\hline $2^{\text {nd }}$ Summer semester & 21801 \\
\hline Fall semester & 42552 \\
\hline
\end{tabular}

\section{Methods}

\section{Solid waste generation}

The university campus is located within the district of Jubaiha, part of the city Amman. The solid waste management department in the district serves the university campus as part of the Jubeiha area. The solid waste collection truck serves the university and surrounding areas with no distinction in route or specialized disposal. Therefore, the collection truck is partially filled when it comes to the university campus. Usually, the solid waste collection vehicle comes twice daily unless there is a need for another collection round. During the study break the truck comes once daily. On measurement days, arrangements had been made with the officials and truck driver to change the truck route to have clear 24 hours with no waste collection on campus then the truck came empty for collecting the solid waste for the entire campus. After collection is completed the truck went directly to weighing station. During the measurement days, the collection truck managed to serve the entire campus in one trip. Difference in truck empty weight and loaded weight was recorded as the weight of the

Fig. 1.

Location of solid waste containers

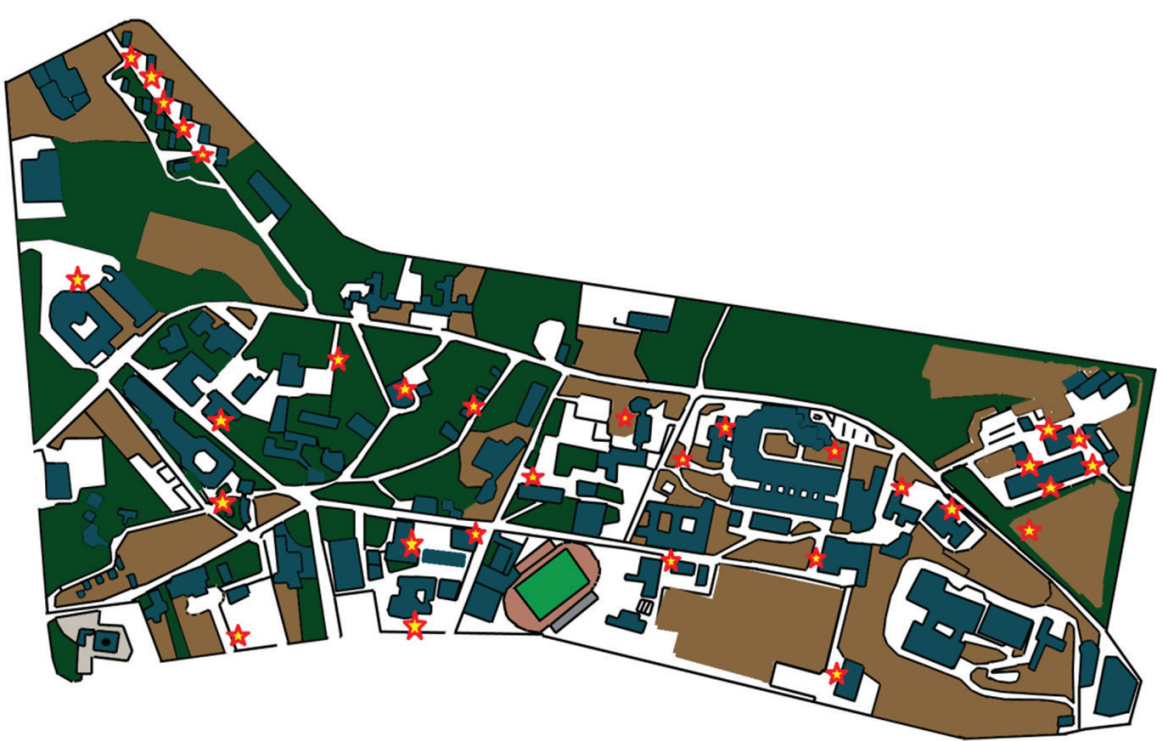


solid waste collected for the collection period. Due to inconvenience in changing the truck collection route, the measurement were done 3 times during the week days and limited to one regular semester.

\section{Waste characterization}

The waste sorting during the entire period of the project followed manual sorting at each containers of the 67 waste container. Waste sorting categories for educational institutions listed in literature showed wide variation (Table 2). Therefore, the categories into which the waste was sorted was determined following visual inspection of the waste containers, initial sampling and results from literature. The categories were mainly determined according to the significant presence in the waste. Eleven major categories were identified. These categories and their main sources are listed in Table 3.

Arrangements has also been made with the collection truck driver to sort the waste few hours before the truck enter the campus area. Sorting crew went to every
Table 3

Solid waste categories and main source

\begin{tabular}{l|l}
\hline \multicolumn{1}{c|}{ Item } & \multicolumn{1}{c}{ Classification } \\
\hline Hot beverages cups & \multicolumn{1}{c}{ Laminated papers cups } \\
\hline Cardboard & Packaging cardboards \\
\hline Plastic & PET, polystyrene and HDPE \\
\hline Metals & $\begin{array}{l}\text { Beverage Containers, tins, ferrous } \\
\text { material, wires, and glass container } \\
\text { caps }\end{array}$ \\
\hline Glass & $\begin{array}{l}\text { Beverages containers and broken } \\
\text { glassware }\end{array}$ \\
\hline Paper & $\begin{array}{l}\text { Office fine paper, glossy paper, lined } \\
\text { answer sheets booklet }\end{array}$ \\
\hline Yard waste & Gardening waste \\
\hline Food & $\begin{array}{l}\text { Pre-processing waste , post process- } \\
\text { ing waste, excess food }\end{array}$ \\
\hline Foil & Wrapping material \\
\hline Other & Meal containers \\
\hline
\end{tabular}

\section{Table 2}

Waste categories listed in literature

\begin{tabular}{|c|c|c|c|c|c|c|}
\hline Reference & $\begin{array}{l}\text { Felder et al } \\
(2001)\end{array}$ & $\begin{array}{l}\text { Mbuligwe } \\
(2002)\end{array}$ & $\begin{array}{l}\text { Armijo de Vega } \\
\text { et al (2008) }\end{array}$ & $\begin{array}{l}\text { Smyth et al } \\
(2010)\end{array}$ & $\begin{array}{l}\text { Taghizadeh et al } \\
\qquad(2012)\end{array}$ & $\begin{array}{c}\text { Sebola et al } \\
(2014)\end{array}$ \\
\hline 1 & 2 & 3 & 4 & 5 & 6 & 7 \\
\hline 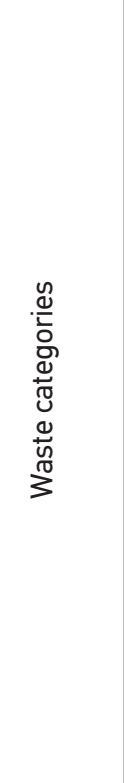 & $\begin{array}{l}\text { Compostable } \\
\text { food } \\
\text { _- Residual paper } \\
\text { _ } \text { Animal bedding } \\
\text { _ Wood material } \\
\text { - Office fine } \\
\text { paper } \\
\text { - Newspaper } \\
\text { - Old corrugated } \\
\text { cardboard } \\
\text { - Recyclable } \\
\text { glass } \\
\text { Recyclable } \\
\text { plastic } \\
\text { Metal } \\
\text { - Residual plastic } \\
\text { - Misc. }\end{array}$ & $\begin{array}{l}\text { Food } \\
\text { waste and } \\
\text { vegetables } \\
\text { Ash } \\
\text { and fine } \\
\text { materials } \\
\text { Tins and } \\
\text { bottles } \\
\text { Paper } \\
\text { Bones and } \\
\text { shells }\end{array}$ & $\begin{array}{l}\text { Paper and } \\
\text { cardboard } \\
\text { _- Plastics } \\
\text { _- Organics } \\
\text { _- Metals } \\
\text { - Glass } \\
\text { - Construction } \\
\text { and demolit- } \\
\text { ion } \\
\text { Hazardous } \\
\text { Other }\end{array}$ & $\begin{array}{l}\text { Paper and } \\
\text { paperboard } \\
\text { _- } \\
\text { beverage cups } \\
\text { Beverage } \\
\text { containers } \\
\text { - Plastics } \\
\text { - Glass } \\
\text { - Expanded } \\
\text { polystyrene } \\
\text { Ferrous metals } \\
\text { - } \text { Non-ferrous } \\
\text { metals } \\
\text { Organic matter } \\
\text { - Hazardous by } \\
\text { products } \\
\text { - Electronic waste } \\
\text { - other }\end{array}$ & $\begin{array}{l}\text { Paper } \\
\text { and paper } \\
\text { products } \\
\text { Plastics } \\
\text { _ Organic } \\
\text { metrical } \\
\text { Glass } \\
\text { - Metals } \\
\text { - Textiles } \\
\text { - Construction } \\
\text { and demolition } \\
\text { Wood } \\
\text { - Hazardous } \\
\text { waste } \\
\text { electronic } \\
\text { waste } \\
\text { other }\end{array}$ & $\begin{array}{l}\text { _- Food } \\
\text { - Other- } \\
\text { biodegradable } \\
\text { _- Polystyrene } \\
\text { _ } \text { Non-categorized }\end{array}$ \\
\hline
\end{tabular}


container within the university fence in rounds, emptied the entire content of the container on a designated plastic tarp, hand sorted the waste into specified buckets, weighted the assigned categories then returned the solid waste to the container before the solid waste collection vehicle come to take the waste. For each studied period except the study break, the content of every container was sorted and weighted at least three times.

\section{Results and Discussion}

\section{Waste generation}

Average solid waste generated from the campus was estimated to be $8113 \mathrm{~kg} /$ day. These results were obtained for the waste generated during a regular semester. Therefore, it was considered as the average upper bound for waste generation from the university campus that would last 160 working days covering the spring and fall semesters. Data from waste generated during the regular semester were used to estimate amount of waste generated during the break and the summer semester based on students' enrolments numbers. Results are listed in table 4.

\section{Table 4}

Waste generation estimation

\begin{tabular}{c|c|c}
\hline Period & $\begin{array}{c}\text { Average amount of } \\
\text { generated waste (kg/day) }\end{array}$ & Note \\
\hline 1 & 2 & 3 \\
\hline Regular semester & 8113 & Measured \\
\hline Break & $4250^{\mathrm{a}}$ & Projected \\
\hline
\end{tabular}

a - in calculating projection, half regular students enrolment and faculty members were assumed

b - Students and faculty members presence on campus during the break assumed $1 \%$ and $20 \%$, respectively.

\section{Waste characteristics}

Solid waste generated from the different sources was sorted and weighted according the procedure described earlier. Sorting crew sorted an average of $1019.64 \mathrm{~kg}$ of solid waste per round during the spring semester and fall semester days. Results from the spring semester and the fall semester were combined and considered as representative of a regular semester. Result of waste sorting process and composition percentages are presented in table 5. According to the waste generation results, amount of waste sorted created about $12.6 \%$ of the total amount of waste generated per day. Waste sorting during study break was conducted during the break between the spring semester and the summer semester. The study break was too short to sort the waste more than once. Other study breaks were also too short to make one complete round. A total of $751.68 \mathrm{~kg}$ of solid waste was processed during the break period. Composition percentages during the study break are presented in table 5 .

The month of Ramadan started in May 26th, 2017 and ended on June 24th, 2017. This period of fasting started few days before the start of the first summer semester. This condition made it necessary to conduct waste sorting during days of fasting and normal days of the first summer semester after the month of Ramadan. Average sorted waste weight per round during Ramadan days was $750.19 \mathrm{~kg}$ of solid waste. Results of waste sorting during days of fasting and normal days of the first summer semester are presented in table 6 . To consider the waste characteristics during summer semester in general, waste was also sorted during the second summer semester days. Average sorted waste weight for the normal first summer semester days and second summer semester were $862.08 \mathrm{~kg}$ and 827.56 $\mathrm{kg}$ of solid waste per round, respectively. To consider waste composition during summer semester days, average composition values for first summer semester and the second summer semester were combined to create composition percentages during summer semester days. Results of summer semester waste composition are presented in table 5. Considering the projected amount of waste generated during the summer semester, average sorted waste created about $20 \%$ of the waste generated.

Results of the sorting process showed that the major components that have significant presence are Hot beverages cups, cardboard, plastic, paper, yard waste, and food waste. Among these main components, plastics in the form of water bottles (PET container with HDPE cap) is the main component with the 
Table 5

Average composition of waste during the different periods

\begin{tabular}{|c|c|c|c|c|c|c|c|c|c|c|c|c|}
\hline \multirow{2}{*}{ Category } & \multicolumn{3}{|c|}{ Regular Semester } & \multicolumn{3}{|c|}{ Break } & \multicolumn{3}{|c|}{ Summer semester } & \multicolumn{3}{|c|}{ Overall } \\
\hline & $\begin{array}{l}\text { Ave } \\
(\mathrm{Kg})\end{array}$ & $\begin{array}{l}\text { Std } \\
\text { Dev. }\end{array}$ & $\%$ & $\begin{array}{l}\text { Ave } \\
(\mathrm{Kg})\end{array}$ & $\begin{array}{l}\text { Std } \\
\text { Dev. }\end{array}$ & $\%$ & $\begin{array}{l}\text { Ave } \\
(\mathrm{Kg})\end{array}$ & $\begin{array}{c}\text { Std } \\
\text { Dev. }\end{array}$ & $\%$ & $\begin{array}{l}\text { Ave } \\
(\mathrm{Kg})\end{array}$ & $\begin{array}{c}\text { Std } \\
\text { Dev. }\end{array}$ & $\%$ \\
\hline 1 & 2 & 3 & 4 & 5 & 6 & 7 & 8 & 9 & 10 & 11 & 12 & 13 \\
\hline Hot beverages cups & 124.44 & 44.4 & 12.2 & 40.89 & - & 5.4 & 87.97 & 13.9 & 10.63 & 74.39 & 48.1 & 8.77 \\
\hline Cardboard & 72.31 & 27.6 & 7.1 & 92.27 & - & 12.3 & 60.72 & 36.3 & 7.34 & 61.89 & 31.9 & 7.30 \\
\hline Plastic & 253.08 & 84.8 & 24.8 & 101.33 & - & 13.5 & 255.15 & 35.7 & 30.83 & 206.77 & 90.8 & 24.38 \\
\hline Metals & 30.97 & 6.1 & 3.0 & 9.45 & - & 1.3 & 27.78 & 7.4 & 3.36 & 24.88 & 9.6 & 2.93 \\
\hline Glass & 57.09 & 27.4 & 5.6 & 6.71 & - & 0.9 & 57.08 & 17.2 & 6.9 & 42.26 & 28.1 & 4.98 \\
\hline Paper & 141.04 & 90.7 & 13.8 & 163.19 & - & 21.7 & 77.89 & 11.9 & 9.41 & 132.39 & 91.9 & 15.61 \\
\hline Yard waste & 110.17 & 36.2 & 10.8 & 193.52 & - & 25.7 & 104.74 & 67.1 & 12.66 & 123.93 & 73.2 & 14.61 \\
\hline Food & 98.18 & 91.0 & 9.6 & 47.44 & - & 6.3 & 62.77 & 33.8 & 7.58 & 89.55 & 75.9 & 10.56 \\
\hline Foil & 1.4 & 1.7 & 0.1 & 1.06 & - & 0.1 & 1.4 & 2.3 & 0.17 & 1.28 & 1.7 & 0.15 \\
\hline Foam & 19.71 & 6.5 & 1.9 & 3.54 & - & 0.5 & 18.56 & 7.6 & 2.24 & 14.20 & 9.4 & 1.67 \\
\hline Other & 111.25 & 92.1 & 10.9 & 92.31 & - & 12.3 & 73.5 & 23.0 & 8.88 & 76.63 & 51.0 & 9.03 \\
\hline Total & 1019.6 & 449.3 & 100 & 751.71 & - & 100 & 827.56 & 102.9 & 100 & 848.19 & 311.3 & 100 \\
\hline
\end{tabular}

Table 6

Waste composition and average sorted waste components weight during the first summer semester

\begin{tabular}{|c|c|c|c|c|c|c|}
\hline \multirow{2}{*}{ Category } & \multicolumn{3}{|c|}{ Ramadan days } & \multicolumn{3}{|c|}{ Normal days } \\
\hline & Ave $(\mathrm{Kg})$ & Std Dev. & $\%$ & Ave $(\mathrm{Kg})$ & Std Dev. & $\%$ \\
\hline 1 & 2 & 3 & 4 & 5 & 6 & 7 \\
\hline Hot beverages cups & 8.36 & 5.6 & 1.1 & 87.34 & 20.9 & 10.13 \\
\hline Cardboard & 43.69 & 30.0 & 5.8 & 75.14 & 48.7 & 8.72 \\
\hline Plastic & 98.86 & 76.6 & 13.2 & 233.41 & 21.2 & 27.08 \\
\hline Metals & 18.12 & 10.6 & 2.4 & 23.59 & 6.4 & 2.74 \\
\hline Glass & 9.67 & 6.1 & 1.3 & 56.06 & 21.7 & 6.50 \\
\hline Paper & 222.5 & 142.7 & 29.7 & 72.27 & 13.8 & 8.38 \\
\hline Yard waste & 152.90 & 120.5 & 20.4 & 162.23 & 35.5 & 18.82 \\
\hline Food & 148.54 & 122.6 & 19.8 & 74.79 & 41.9 & 8.67 \\
\hline Foil & 1.46 & 1.0 & 0.2 & 1.93 & 3.3 & 0.22 \\
\hline Foam & 3.54 & 3.8 & 0.5 & 17.02 & 8.8 & 1.97 \\
\hline Other & 43.03 & 46.4 & 5.7 & 58.31 & 23.6 & 6.75 \\
\hline Total & 750.67 & 537.3 & 100 & 862.08 & 99.8 & 100 \\
\hline
\end{tabular}


highest contribution to the waste stream. Although, plastics presence during the break and Ramadan dropped remarkably, it's contribution remains significant. Effect of summer on people's consumption of water can also be seen on increasing the amount of disposed plastic water bottles during the summer semester.

Over the study four periods, hot beverages cups, plastics, metals, glass and food waste are closely related to the presence of students on campus. Paper waste seems to increase during the break, which could be related to cleaning up the faculty offices and school's buildings after final exams. Yard waste maintained significant contribution to the total waste regardless of the presence of students on campus. Hot beverages cups and plastic percentages dropped significantly during the month of Ramadan which is related to the fasting during the day. On the other hand, food waste increased during the month of Ramadan which was unexpected. After talking to the main restaurant management, they revealed that the main restaurant on campus open it's doors for service during sunset time and frequently hosts gathering events for breaking the fasting at sunset time during the month of Ramadan. They also cater several students gathering events for breaking their fast that usually take place on campus. Foil and foam had a notable presence in the waste stream but did not have remarkable contribution to weight of the waste due to their density. Glass and metals had considerable presence during students' study periods. During the break and Ramadan, glass and metals dropped to insignificant levels.

Comparing results of the waste composition during the first summer semester, where it included some days of Ramadan, shows a distinct differences in waste characteristics during the normal days and the days of fasting. Food containers such as hot beverages cups, plastic, glass, foil and foam percentages dropped drastically while food percentage itself increased. Paper percentage, on the other hand, increased significantly.

\section{Recycling potential}

The information provided by the characterization study can be used by the university administration as insight for potential recycling and waste reduction strategies.
Extent of waste recycling and variation over the academic year will be influential factors in deciding appropriate approaches and validity of the proposed actions. Results from the characterization study were reformulated to give general information and predict recycling and waste reduction potential. Reformulation was based on considering three categories: compostable (food waste and yard waste), recyclable waste and non-recyclable waste. These categories are presented in table (7). Results from reformulation show that at least $87 \%$ of the waste stream generated on campus during regular semester, break and summer semester can be diverted from going to landfill. This percentage increased to $93 \%$ during the month of Ramadan. These percentages can be translated into potential of recycling over $7050 \mathrm{~kg}, 3690 \mathrm{~kg}, 690 \mathrm{~kg}$ of daily waste during regular semester, summer semester, study break, respectively. Compared to available literature, recyclable components percentages are higher than Armijo de Vega et el (2008) who estimated it to be $66 \%$ and Taghizadeh et al (2012) who reported $80 \%$ recycling and waste reduction potential. Further comparison shows that compostable material in this study (25\%) is significantly lower than Sebola et al (2014) (35\% in general waste and 93\% in garden waste) and Mbuligwe (2002) (40-67.6\%). These difference can be related to the size of the university and cultural differences.

\section{Table 7}

Waste composition percentages according to recycling potential

\begin{tabular}{l|c|c|c|c|c}
\hline \multicolumn{1}{c|}{ Item } & $\begin{array}{c}\text { Regular } \\
\text { Semester }\end{array}$ & Break & Ramadan & $\begin{array}{c}\text { Summer } \\
\text { semester }\end{array}$ & Overall \\
\hline 1 & 2 & 3 & 4 & 5 & 6 \\
\hline Compostable & 20 & 32 & 40 & 20 & 25 \\
\hline Recyclable & 67 & 55 & 54 & 69 & 64 \\
\hline Non-recyclable & 13 & 13 & 6 & 11 & 11 \\
\hline
\end{tabular}

Results from the characterization study have been used to forecast expected daily components weight during the regular semester, summer semester and study break and the total expected production for the year. Forecasted data are presented in table 8 . Although, these numbers are considered theoretical as recycling programs requires clean and 


\section{Table 8}

Projected daily and yearly components weight ${ }^{a}$

\begin{tabular}{l|c|c|c|c}
\hline \multirow{2}{*}{ Components } & \multicolumn{3}{|c|}{ Estimated Generation (kg/day) } & $\begin{array}{c}\text { Estimated } \\
\text { generation } \\
\text { (kg/yr) }\end{array}$ \\
\cline { 2 - 5 } & Regular & Summer & Break & 5 \\
\hline Hot beverages cups & 990 & 452 & 43 & 191286 \\
\hline Cardboard & 578 & 312 & 98 & 117342 \\
\hline Plastic & 2012 & 1310 & 108 & 416883 \\
\hline Metals & 243 & 143 & 10 & 49250 \\
\hline Glass & 454 & 293 & 7 & 93436 \\
\hline Paper & 1120 & 400 & 174 & 212338 \\
\hline Yard waste & 876 & 538 & 206 & 184024 \\
\hline Food & 779 & 322 & 50 & 148678 \\
\hline Foil & 11 & 7 & 1 & 2347 \\
\hline Foam & 157 & 95 & 4 & 31967 \\
\hline Other & 884 & 377 & 98 & 170861 \\
\hline Total & 8113 & 4250 & 800 & 1619580 \\
\hline & & & & \\
\hline
\end{tabular}

${ }^{a}$ forecasting yearly production was based on 160 days during regular semester, 70 days during summer semester and 30 days during the break

uncontaminated material, these percentages and amounts remain significant and indicate high potential for recycling and diverting immense amount of the waste from ending in the landfill.

Hot beverages cups, cardboard, plastics, paper and food waste may be considered as the prime candidates for recycling activities on campus. Plastic contribution to the waste stream was found to be the biggest, it creates about $25 \%$ of the waste stream overall and during regular semesters. It drops to $13 \%$ during the break and Ramadan time and increases to 30\% during the summer semester. Plastics percentages reported in literature were remarkably inconsistent. Felder et al (2001) reported 13\%, Smyth et al (2010) reported around 7.9-8.3\% Taghizadeh et al (2012) reported $0.11-38.83 \%$ and de Vega et al (2008) reported $3-8.2 \%$. Due to the wide difference in reported data, plastics percentages for this study can be considered within the literature report. Plastic recycling has been practiced in different levels globally and locally.
Recycling plastic waste from campus waste stream will require two stages of separation: separation from waste stream and separation of plastic according to the chemical composition. If properly handled, generated amounts of plastic waste could become an income source if used in recycling industry.

Hot beverages cups create about $12.2 \%$ of the waste stream. It's contribution to the waste stream dropped during the break and Ramadan then increased to about $10.6 \%$ during the summer semester. These results were higher than Smyth et al (2010) who reported 4.6$6.0 \%$. This difference could be related to difference in size of the university and number of enrolment. Considering the light weight of the cups, number of consumed hot beverages cups is enormous. Recycling of cups is challenging as cups are basically paper laminated with plastic layer. Therefore, according to paper recyclers it is already contaminated with another material making it less recyclable. Choices for the university administration could be following these limited recycling options or enforcing the use of biodegradable cups, that might be used in composting, or reusable cups on campus.

Paper creates $13.8 \%$ and $9.4 \%$ of the waste stream during regular semesters and summer semester, respectively. Paper contribution increased during the break and the month of Ramadan reaching $21.7 \%$ and $29.7 \%$, respectively. Results were relatively consistent with Felder et al (2001) and Taghizadeh et al (2012) but lower than de Vega (2008) who reported papers and cardboard percentage up to $43 \%$. Similar to paper cups but to a lesser extent, paper recycling requires careful monitoring. Buyers of used paper rejects batches contaminated with spilled coffee. Although, recycling the paper requires no contamination of paper, the characterization study results infer that paper recycling is promising. Should the university administration choose to utilize paper recycling programs, careful monitoring would be needed to maximize paper recycling on campus. Other opportunity of recycling paper might be in the form of composting with other organic materials.

Yard waste contribution to waste stream varied from $10.8 \%$ to $25.7 \%$. Main direction for diverting the yard waste from going to the landfill is toward composting. Local composting of the yard waste might support the 
gardening activities on campus and reduce fertilizers expenses. Currently, the gardening department buys fertilizers and compost from local suppliers. Constructing a composting facility will reduce the waste generated and release some of the gardening pressure on the university budget.

Food waste contribution to the waste stream is $9.6 \%$ during regular semesters, $6.3 \%$ during the break, $19.8 \%$ during Ramadan, and around $7.6 \%$ during the summer semester. These results were lower than percentages reported in Mbuligwe (2008) and Sebola et al (2014). Differences may be related to cultural differences. Food usually dumped in containers can be divided into three categories:

Product of cooking and food pre-processing waste.

Product of cleaning dishes and leftover from unfinished meals. Usually food waste in this category is mixed with wrapping and packaging material.

Extra food leftover in trays and cooking pans. Rice represent the major part of it. Usually dumped clean.

Food waste can be used in campus greening or humanitarian activities. Thrown food waste can be mixed with yard waste then composted to be used later as natural fertilizer. Use of food waste as a source of energy is also a viable option. Bioconversion of food waste to energy in the form of ethanol, hydrogen or methane can be economical (Kiran et al , 2014). Biogas produced from food waste can give $2.3 \mathrm{MWh}$ / tonne dry waste (Curry and Pillay, 2012). Assuming 75\% moisture content, yearly generation of food waste may generate up to $85 \mathrm{MWh}$. Another opportunity would be to intervene before throwing the food and sending the clean part of it to food banks.

Cardboard, glass and metals are another contributors to the waste stream. In spite of the fact that they are the smallest contributors, their recycling opportunities may be considered as the easiest choices. Recycling cardboard, glass and metals is practiced in Jordan and is not uncommon to the Jordanian community. Local businesses are recycling these products on different scales. Therefore, these components might provide valid opportunities for recycling.

Observing aforementioned results, recycling in the university of Jordan is promising and wide range of opportunities are present. Comparing current cost to potential recycling activities, recycling can be profitable as in the case of using food waste and yard in generating biogas to be used later as an energy source. Each of these recycling areas require separation at source or at a sorting facility and an awareness program to support these proposed activities. Recycling initiatives over the years have shown than attitude toward recycling can be easily changed and adopted but it requires full implementation. Taking into account the generation level for the University of Jordan, the scale of recycling waste components can be handled better at a management level higher than recycling initiatives run by students. Designated department for waste management and recycling will be the best choice to ensure proper and safe handling of the waste and sustainable programs.

\section{Conclusions}

The characterization study has been conducted to the waste generated from the University of Jordan area over four distinct periods: regular semester, study break, the month of Ramadan, and the summer semester. The study showed that waste generated from the university campus reaches an average of $8113 \mathrm{~kg} /$ day during the regular semester with full enrolment of students. The study projected waste generation will reach $4250 \mathrm{~kg} /$ day and $800 \mathrm{~kg} /$ day during the summer semester and the break, respectively. The study presented that at least $87 \%$ of the waste stream from the university main campus can be diverted from going to landfill. This amount can be recycled, reused, or used as an energy source. The study revealed that the major recyclable components that have significant presence are hot beverages cups, cardboard, plastic, paper, yard waste, and food waste. The study results showed that recycling program on campus is highly recommended but requires full scale cooperation and careful handling.

\section{Acknowledgements}

Author thanks the Deanship of Academic Research at the University of Jordan for funding this project. Also, the author would like to thank Mr. Raed Alsisan for his role in arrangement of the sorting teams and data acquisition. 


\section{References}

Armijo de Vega, C., Benitez, S., and Ramirez-Barreto, M., (2003) "Mexican educational institutions and waste management programmes: a University case study" Resources, Conservation, and Recycling, Vol. 39: 283-296. https://doi.org/10.1016/ S0921-3449(03)00033-8

Armijo de Vega C., Benítez S., Ramirez-Barreto, M., (2008). "Solid waste characterization and recycling potential for a university campus". Waste Management Vol. 28: S21-S26. https://doi. org/10.1016/j.wasman.2008.03.022

Curry, N., and Pillay, P., (2012) "Biogas prediction and design of food waste to energy system for the urban environment", Renewable Energy, Vol. 41: 200-209. https://doi.org/10.1016/j. renene.2011.10.019

Felder, M., Petrell, R., and Duff, S., (2001). “A solid waste audit and directions for waste reduction at the university of British Columbia, Canada". Waste Management and Research, Vol. 19:354-365. https://doi.org/10.1177/0734242X0101900412

Kiran E., Trzcinski, A., Ng, W., Liu, Y., (2014) “Bioconversion of food waste to energy: A review”, Fuel, Vol. 134: 389-399. https://doi.org/10.1016/j.fuel.2014.05.074

Mason, I., Brooking, A., Oberender, A., Hardford, J., and Horsley, P., (2003). "Implementation of a zero waste program at a university campus", Resources, Conservation, and Recycling, Vol.
38,:257-269. https://doi.org/10.1016/S0921-3449(02)00147-7

Mbuligwe S., 2002. "Institutional solid waste management practices in developing countries: a case study of three academic institutions in Tanzania, Resources, Conservation and Recycling, Vol. 35: 131-146 Sebola, R., Mokgatle, L., Aboyade, A., and Muzenda, E., (2014). "Solid Waste Quantification for the University of Johannesburg's Waste to Energy Project”, Int'L Journal of Research in Chemical, Metallurgical and Civil Engg Vol. 1 (1):84-88.

Smyth, D., Fredeen, A., and Booth, A. (2010). " Reducing solid waste in higher education: The first step towards "greening' a university campus", Resources, Conservation and Recycling , Vol. 54: 1007-1016. https://doi.org/10.1016/j. resconrec.2010.02.008

Taghizadeh, S., Ghassemzadeh, H., Vahed, M., and Fellegari, R., (2012). "Solid waste characterization and management within university campuses case study: university of Tabriz", Elixir Pollution. Vol 43:6650-6654.

Tchobanoglous G, Theisen H, Vigil S., 1996. "Integrated solid waste management”. New York, NY, USA: McGraw-Hill.

UNEP (United Nations Environment Programme), (2009). “Developing Integrated Solid Waste Management Plan: Training Manual, Volume 4. ISWM Plan.
Kietųjų atliekų tvarkymas švietimo įstaigose: Jordanijos universitetas

\section{Shadi Moqbel}

Jordanijos universiteto Civilinès inžinerijos katedros docentas, Jordanija

Darnus vystymasis priverte besivystančias šalis tiksliai pažvelgti i savo atlieku tvarkymo sistemą, ¡skaitant švietimo istaigas. Šiame darbe Jordanijos universitete buvo atliktas atlieku apibūdinimo tyrimas. Siūlomas paprastas kietuju atlieku rūšiavimo būdas didelèms istaigoms. Tyrime buvo atlikti atlieku susidarymo greičiui jvertinimai, kietu atlieku, susidariusių miesteliuose, charakteristikos ir ju skirtumas per keturis skirtingus laikotarpius akademiniame kalendoriuje: reguliarus semestras, studiju pertrauka, vasaros semestras ir Ramadano ménuo. Tyrimas parodè, kad per reguliarius semestrus universiteto miestelyje kasdien susidaro $8113 \mathrm{~kg}$ atlieku. Iš rezultatu matyti, kad mažiausiai 87\% esančių atliekų gali būti perdirbamos. Kad būtų užtikrintas tvarus kietujjų atliekų tvarkymas ir patikima perdirbimo programa, turi būti vykdoma universitetu atliekų tvarkymo programa.

Raktiniai žodžiai: kietosios atliekos, perdirbimas, švietimo istaiga. 